\title{
The evolution and revision of big deals: a review from the perspective of libraries
}

\author{
Blanca Rodríguez-Bravo; Andrés Fernández-Ramos; Marta De-la-Mano; Marina \\ Vianello-Osti
}

Nota: Este artículo se puede leer en español en:

http://www.profesionaldelainformacion.com/contenidos/2021/jul/rodriguez-fernandez-de-la-mano-vianello_es.pdf

How to cite this article:

Rodríguez-Bravo, Blanca; Fernández-Ramos, Andrés; De-la-Mano, Marta; Vianello-Osti, Marina (2021). “The evolution and revision of big deals: a review from the perspective of libraries". Profesional de la información, v. 30, n. 4, e300415.

https://doi.org/10.3145/epi.2021.jul.15

Manuscript received on April, $15^{\text {th }} 2021$ Accepted on June, $25^{\text {th }} 2021$

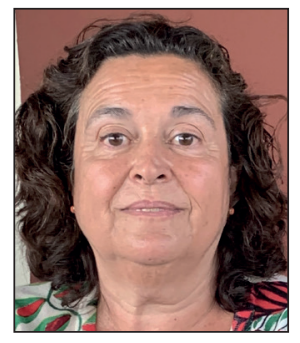

Blanca Rodríguez-Bravo $\square$ https://orcid.org/0000-0002-9476-7602

Universidad de León

Dto. de Patrimonio Artístico y Documental Área de Biblioteconomía y Documentación Campus de Vegazana, s/n.

24071 León, Spain

blanca.rodriguez@unileon.es

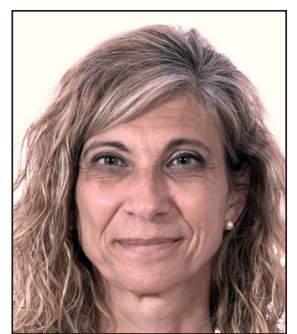

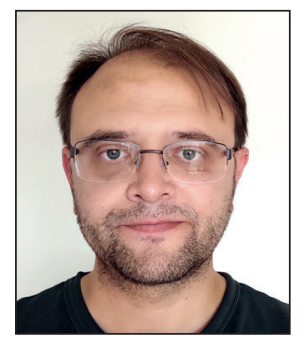

Andrés Fernández-Ramos https://orcid.org/0000-0002-6869-602X

Universidad de León

Dto. de Patrimonio Artístico y Documental Área de Biblioteconomía y Documentación Campus de Vegazana, $\mathrm{s} / \mathrm{n}$.

24071 León, Spain

afernr@unileon.es

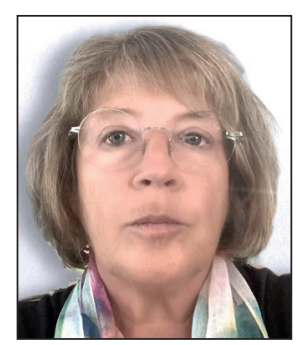

Marina Vianello-Osti

https://orcid.org/0000-0002-8745-3947

Universidad Carlos III de Madrid Departamento de Biblioteconomía y Documentación

Madrid, 126-128

28903 Getafe (Madrid), Spain

mvianell@bib.uc3m.es

\begin{abstract}
We study the phenomenon of the big deal, a subscription model for scientific journals that emerged at the turn of the millennium aimed especially at library consortia, which were offered the opportunity to exponentially increase their access to scientific information, thus breaking the previous trend of continuous cuts to the collections of the periodicals available in libraries. Its strengths such as the expansion of the availability of content, and its impact on the diversification of use and the productivity of researchers are presented herein. Likewise, its weaknesses are highlighted, such as the constant increase in prices and the finding of the concentration of use in a limited set of content. These disadvantages have led to questioning and resulted in the evaluation of big deals, a search for alternatives, and cancellations in times of crisis. In recent years, the latter have been linked to the perception that the cost-benefit balance of big deals has been altered by the proliferation of open-access content. Finally, we address the revision of the traditional big deal through transformative agreements where subscription costs are offset by publication costs, which are intended to be a mechanism to accelerate the transition to open access.
\end{abstract}

\section{Keywords}

Open access; Transformative agreements; Big deals; Scientific journals; University libraries; Collection evaluation; Electronic journals; Subscriptions. 
Financiación

This research has been funded by the State Program for Research, Development and Innovation Oriented to the Challenges of Society 2017, convened by the Spanish Ministry of Economy, Industry and Competitiveness and the Spanish State Research Agency (CSO2017-87956-R), and by the program of grants designed to support the recognized research groups of public universities in Castile and Leon that began in 2018, convened by the Ministry of Education of the Government of Castile and Leon (LE028G18).

\section{Introduction}

The term "big deal" was coined in early 2001 by Kenneth Frazier, director of the libraries at the University of Wisconsin-Madison, who defined it as

"an online aggregation of journals that publishers offer as a one-price, one size fits all package" (Frazier, 2001a).

The term had ironic connotations, as Frazier predicted that this model would create dependency on contracted products, enable large commercial publishers to control prices, shift tasks traditionally performed by large journal publishers and subscription agencies to libraries, and increase the vulnerability of libraries to any change in content subscription.

Many electronic information packages have been sold to libraries by publishers over more than 20 years, some multidisciplinary and others specialized. Among the former are those of the major publishers, namely Elsevier, Springer, Taylor \& Francis, and Wiley. These are the ones that distribute a greater amount of content. Among the specialized big deals, one can mention those offered by Emerald and the IEEE. All of them have a general presence in university and research libraries.

Thus, practically all the major publishers of scientific journals opted for this model at the turn of the millennium. The big deal was favored by the popularization of the electronic format, and stimulated the strengthening and generation of library consortia, which were offered the opportunity to significantly increase their access to scientific information, bucking the previous trend of continuous cuts in library collections of periodicals, whose management was based on subscription title by title, metaphorically known as "cherry picking." This earlier model led to what came to be called the serials crisis, caused by the rapid increase in subscription costs for periodicals above the rate of inflation and library budgets.

The resulting formula seemed beneficial to both parties: the large publishers ensured stable profits, since the institutions continued to pay based on the collection previously subscribed to on paper plus a little more for access to content that they previously did not have, which also allowed them to sell journals of secondary interest that few libraries might otherwise acquire. Furthermore, negotiating with consortia allowed them to reduce the number of intermediaries and points of contact.

For libraries, this model made it possible to overcome the journal crisis experienced in the 1990s and increase access coverage, which moved online, obtaining an average price per subscribed journal that was lower than they paid through paper subscriptions. Likewise, this has allowed both publishers and libraries to maintain a more stable relationship without negotiations on an annual or detailed, title-by-title basis. Libraries have thus greatly reduced the administrative work associated with subscribing to paper journals, including loss of copies in the mail and continual complaints about missing issues. Still, managing licenses and electronic resources is far from easy.

Finally, the model has been based on the recognized acceptance of these packages by researchers and on the apparent benefits that easy access to a wide range of journals seems to have for the use of content and consequently the productivity of academics. Thus, the profits from big deal contracts cannot be measured exclusively in financial terms, but also in terms of the teaching and research effectiveness of the university community. The greater availability of publications has resulted in an increase in the use of journals and, consequently, greater scientific progress (Fernández-Ramos et al., 2019; Rodríguez-Bravo; Alvite-Díez, 2013; Rodríguez-Bravo et al., 2012). Other benefits that have been observed and related to scientific communication guidelines have been the increase in references per published work and the reduction in the rate of reuse of the same references by authors.

Over time, however, the value of big deals has become less apparent, as publishers have increased the price of packages over and above the increases in library budgets, forcing libraries to allocate much of their economic resources to maintaining these contracts while also losing the ability to design bespoke collections that are more appropriate for their academic communities (Bergstrom et al., 2014). Thus, what was initially an easy way to enlarge their journal collections at a good price has become a restrictive agreement that limits the financial and strategic flexibility of universities. Hence, a growing number of libraries have questioned these big deals and begun to reevaluate their collections, estimate the value that they are receiving from these packages, and consider how to spend the resources dedicated to their collection in a more strategic way.

The big deal model has been based on the recognized acceptance of these packages by researchers and on the apparent benefits that easy access to a wide range of journals seems to have for the use of content and thereby the productivity of academics 
On the other hand, the scholarly publishing system has been widely considered to be "broken," citing as evidence the levels of profits generated by publishers. They have tried to justify their prices based on increases in costs, their investments in technology, and the added value they bring (Björk, 2021). However, there is evidence that the subscription market does not work efficiently because the products that are marketed, i.e., scientific publications, cannot be substituted by others, as well as excessive market concentration and a lack of transparency, among other factors (Johnson, 2019). According to Björk (2021), the main cause of the problem is not market concentration, a situation that is common to other industries, but the fact that the big deals of different publishers are complementary and not substitutes, which implies that publishing companies do not compete for customers, unlike in other industries with a high degree of concentration such as mobile telephony.

Reports by the European University Association (Morais; Bauer; Borrell-Damián, 2018; Morais; Stoy; Borrell-Damián, 2019) have confirmed the magnitude of the costs of big deals in Europe, with the main expense being on scientific journals. Likewise, great disparity in their prices is observed, and publishers generate stable profits while university budgets suffer cuts. Thus, the owner of Elsevier, RELX Group, increased its profit margin from 5\% in 2014-2015 to 6\% in 2015-2016 and 2016-2017. If these data are compared with the funding trends that are collated annually by the EUA Public Funding Observatory, it can be seen that, in the 2008-2016 period, only Austria, Germany, and Sweden showed sustained investment in terms of university funding in relation to growth in student enrollment, while 19 countries suffered budget cuts (Pruvot; Estermann; Kupriyanova, 2017). The European university sector thus operates under severe financial pressure.

In this context, it is necessary to address the role that big deals have played and continue to play in the scientific communication ecosystem and reflect on their validity as well as possible alternatives. This paper presents a literature review on the big deal model of subscription to electronic journals, emphasizing its strengths and weaknesses, the crises it has experienced, the questions it has raised, alternatives for access to content, and its recent revision through transformative agreements.

\section{Benefits and drawbacks of the big deal}

When publishers began offering big deals in the late 1990s, there was no formula for determining their price. Most of the contracts were based on the cost of the previous paper subscriptions of each institution with the corresponding publisher, plus an increase of between $5 \%$ and $15 \%$ in exchange for access to a considerable number of titles that were not previously subscribed to. The duration of the contracts was across multiple years, ranging between 3 and 5, with an annual increase of around 6\% (Bergstrom et al., 2014). However, their implementation differed according to the various initial situations of journal subscriptions in each country. Following the initial contracts, the libraries found themselves trapped, since not renewing the subscription would mean reducing their service to users (Björk, 2021).

In order to negotiate with large publishers, it became clear that university libraries had to collaborate with each other (Wenzler, 2017), being consortia the most appropriate means to strengthen their negotiating position. Library consortia appeared on the library scene in the late 1990s. Their spread has continued worldwide, while their influence has also expanded considerably. Consortia represent, in fact, a second wave of cooperation. The first took place in the 1970s and 1980s and focused on library automation (having important consequences for interlibrary loans). This second wave aimed to enhance electronic information and, therefore, had a great impact on library collections (Anglada, 2003).

Consortia played a leading role in achieving savings in the acquisition of electronic resources, since they had greater negotiating power and could reach better agreements. Thomas Sanville, executive director of the OhioLINK consortium between 1992 and 2010, mastered economies of scale and applied his knowledge and experience to boost big deals with a considerably reduced price for each item of information (Ingenta Institute, 2002).

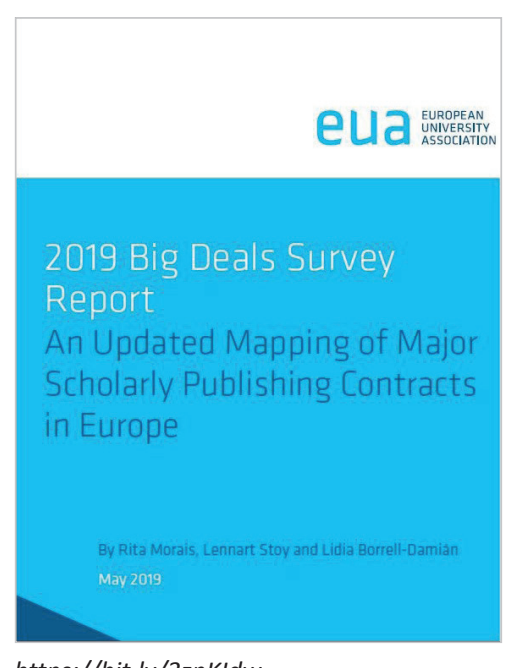

https://bit.ly/3znKIdw

As shown by reports from the European University Association, an essential activity of consortia today continues to be the negotiation of contracts, ahead of other essential functions such as analysis of the needs of their member libraries, production and distribution of statistics, acquisition of resources, and payment of suppliers, all of which are also essential activities for this type of organization (Morais; Bauer; Borrell-Damián, 2018; Morais; Stoy; Borrell-Damián, 2019).

\subsection{Benefits of the big deal: increased availability and use of publications}

In the first two decades of the 21st century, the big deal formula has made it possible to consolidate the collections of large university libraries and made it easier for small and medium-sized libraries to access a volume of content that was 
never imagined. As early as 2001, Sanville highlighted the benefits of the growth in the number of periodicals available and noted that libraries were experiencing a major change in mindset from "I know what my users need," which governed the selection of publications in the collections of printed journals, to the "let's find out what my users need," which facilitated subscriptions to electronic journal packages.

This new point of view, called the "long tail" by Anderson (2006), refers to an increase in supply and subsequent increase in demand. As Dempsey (2006) points out, this increase in supply made it easier for readers to discover and access the content they needed. Given the highly varied needs and preferences of researchers, even within the same area of knowledge, this availability of a wide range of resources is highly valued by users. In general, scientific disciplines receive the greatest benefit because they are better covered by the content included in the main big deals.

In this regard, use studies have revealed that the greater availability of journals has indeed produced a wide diversification of use, including titles that were not previously subscribed to on paper, and in many cases even prioritized over them (Baker, 2008; Ball, 2004; Borrego, 2005; Franklin, 2005; Nicholas; Huntington, 2006; Frazier, 2001a; 2001b; Rodríguez-Bravo; Alvite-Díez, 2006a; 2006b; Rowse, 2003; Sanville, 2001; Urbano et al., 2004). This situation can be illustrated by the case of the Ohio universities, where as Sanville $(2001 ; 2003)$ and Mulliner (2003) point out, half or more of the titles used in most of the consortium's universities were not available previously on paper.

In addition to this diversification, numerous studies have also revealed a clear upward trend in the consumption of content from journals included in the big deals (Boukacem-Zeghmouri; Schöpfel, 2008; Boukacem-Zeghmouri et al., 2016; Fernández-Ramos et al., 2019; Gorraiz; Gumpenberger; Schlögl, 2014; Rodríguez-Bravo et al., 2008; Rodríguez-Bravo; Alvite-Díez, 2011; Rodríguez-Bravo; Alvite-Díez; Barrionuevo-Almuzara, 2012; Rodríguez-Bravo et al., 2012; Tripathi; Kumar, 2014; Tetteh, 2018). As an example, 67 universities in the UK doubled their downloads between the academic years 2003-2004 and 2006-2007 with an annual growth rate of 21.7\% (Ciber, 2009).

Likewise, it has been considered that, financially, in relative terms (price per item), the big deal was a good deal in the beginning. The magnitude of the gain provided by this model can also be confirmed in the Spanish case (Urbano et al., 2004; Rodríguez-Bravo; Alvite-Díez, 2013), especially when the "serials crisis" was leading to continuous cancellations.

The big deal model has been in force for more than two decades, without suffering major changes in most cases. This model has been sustained by the inertia resulting from the flattening of the publisher-library-user relationship due to the commercialization of all publisher's products. This has made it easier for publishers to sell their entire catalog, including both titles that are well accepted as well as others. For libraries, the model has made it possible to overcome the serials crisis experienced in the 1990s and increase the size of their collections, obtaining an average price per subscribed journal that is lower than that paid for paper subscriptions. Finally, the model has survived in part based on the recognized acceptance of these packages by researchers and the apparent benefits of easy access to a wide range of journals on the use of content and thereby the productivity of academics.

\subsection{Drawbacks of the big deal: constant price increases and concentration of use}

However, this library-publisher idyll was soon broken by the permanent increase in the prices of the packages in successive renewals, a problem that was exacerbated in times of economic recession and budget freezes for academic libraries. In this sense, it has been shown that maintaining electronic resource contracts consumes most of library budgets, to the detriment of other investments such as subscriptions to journals that are not included in packages as well as monographs.

Another source of malaise has been that libraries face serious difficulties in comparing and negotiating the prices of subscriptions to these packages under optimal conditions, since due to confidentiality policies, they do not have access to information on the prices that the providers charge to other clients (Bergstrom et al., 2014; Boukacem-Zeghmouri et al., 2016; Blecic et al., 2013; Frazier, 2005; Shu; Mongeon; Haustein et al., 2018). As long as 15 years ago, the European Commission (2006) requested that selected journals have an individualized price and that the charges for the packages be made known, thereby avoiding such substantial price variations.

Added to these drawbacks was the realization that, although a priori the demand for information is elastic, the search for information on big deals is concentrated in a limited number of reputable titles that are linked to obtaining stability and/or promotion in academia. Since the first download studies were carried out, it has been observed that the intensity of use is limited while the concentration of use is high. The use of content is thus focused on a small number of titles (Conyers; Dalton, 2007; Urbano et al., 2004; Evans et al., 2005; Fernández-Ramos et al., 2019; Rodríguez-Bravo et al., 2008; Rodríguez-Bravo; Alvite-Díez, 2011; Rodríguez-Bravo; Alvite-Díez; Barrionuevo-Almuzara, 2012; Sanville, 2001). Likewise, studies based on surveys conducted with
This model has been sustained by the inertia resulting from the flattening of the publisher-library-user relationship due to the commercialization of all of the publisher's products 
academics have shown that researchers consult a small number of titles -rarely more than ten- and tend to opt for reputable titles (Rodríguez-Bravo; Alvite-Díez; Olea, 2015; Tenopir; King, 2002). The correspondence between the titles consulted and the journals chosen to communicate research is limited, an effect that occurs because academics read better-positioned journals than those in which they finally manage to publish their research (Rodríguez-Bravo; Alvite-Díez; Olea, 2015; Rodríguez-Bravo et al., 2013; Tenopir; King, 2002). This fact suggests that offering a large amount of secondary content does not necessarily lead to greater use.

Specifically, it has been observed that the distribution of downloads largely matches the Pareto or Bradford principle (Emrani; Moradi-Salari; Schöpfel; Leduc, 2012; Singson; Hangsing, 2015; Srivastava; Kumar, 2018; Zhu; Xiang, 2016). This principle, long known in the management of services and printed collections in libraries (Britten, 1990; Trueswell, 1969), establishes an $80 / 20$ distribution between two variables, such that $20 \%$ of one of them explains $80 \%$ of the other (Nisonger, 2008). In the case of the use of electronic journals, this means that approximately $80 \%$ of the downloads correspond to $20 \%$ of the titles contracted. Along these lines, Tay (2019) recently indicated, with respect to one of the big deals contracted by the University of Singapore, that $75 \%$ of the downloads were from $10 \%$ of the journals included in the package.

Citation analysis also allows an evaluation of the usefulness of journals. According to Shu et al. (2018), researchers cite only a fraction of the journals subscribed to by their libraries, and that fraction is decreasing, causing the subscribed journal packages to lose value.

Likewise, subscriptions to identical collections by all universities regardless of their volume of personnel, the degrees they teach, and their areas of knowledge came to be questioned. In fact, the use of the main big deals is uneven, as can be deduced from studies carried out on download statistics for various big deals such as those cited above. The possibility of a bespoke offering tailored to the needs of each institution has been advocated repeatedly, albeit without much success. It was quickly confirmed that libraries needed to regain their ability to select and tailor collections. As early as 2004, Gatten and Sanville asked whether it would not be easier and less expensive to acquire from the publisher only those titles that suit their users.

By being able to identify the interests of the different research communities thanks to download statistics, the idea that customized packages should be the way forward has gained momentum, as highlighted by declarations made by Icolc (2010). Such à la carte offerings were also the formula indicated by the European Commission (2006), which stated that libraries should be able to select their publications and construct their own packages. Prices could be established for different size sets of content according to transparent criteria. Being aware of the existence of usage patterns common to various institutions would allow providers to configure appropriate packages. Understanding the specific use profiles in the institutions themselves would allow libraries to select some content collections over others. In this regard, Mongeon et al. (2021) recently recommended that universities share bibliographic resources in a coordinated way and negotiate strategies with publishers based on shared interests and use trends.

\section{The impact of the Great Recession: the first cancellations and alternative approaches to the big deal}

Questioning of the big deal started early in the USA. Even Sanville, one of its main proponents, began to consider its withdrawal as early as 2004 due to the large increases in annual costs (Gatten; Sanville, 2004). The start of the Great Recession in 2008 sharpened this process and promoted the search for alternatives to this model. As Stachokas (2018) points out, this crisis hit higher education especially hard, and had long-lasting negative consequences on a global scale. For many academic libraries of all sizes, this was a time of budget cuts, salary freezes or limited raises, and forced cancellation of many journal subscriptions.

In order to better understand the negative impact of the Great Recession on libraries, Nicholas et al. (2010) analyzed the results of a global survey conducted by the Charleston Observatory with 800 responses, along with those of a study based on a focus group of 16 librarians from British universities. Among the academic librarians, $27 \%$ admitted budget reductions of more than $10 \%, 16.8 \%$ reported reductions of less than $10 \%$, while $39.45 \%$ indicated that their budgets were frozen.

Meanwhile, Lowry (2011) analyzed the results of a survey of 123 members of the Association of Research Libraries $(A R L)$ regarding the crisis in fiscal years 2008-2009 and 2009-2010. Of the $74 A R L$ members who responded, $77 \%$ had 
experienced budget cuts of between $0.01 \%$ and $22 \%$ in 2009-2010. But if $A R L$ member libraries went through a difficult period in those years, the impact of the crisis on small libraries was much greater, as confirmed by data from the National Center of Education Statistics (Regazzi, 2012). Spending on electronic journals by large libraries continued to rise between 2008 and 2010, yet the increase was zero for very small libraries. Attempts were also made to reduce the cost of journal packages and their impact on battered library budgets. Thus, the Research $\mathrm{Li}$ braries of the United Kingdom $(R L U K)$, the equivalent of the ARL in North America, adopted a two-pronged strategy in 2010-2011 to pressure Wiley and Elsevier to reduce the cost of their journal packages. Plan A consisted of three requests agreed by the 21 member libraries in October 2010: (1) the return to 2007 costs, meaning an effective reduction of 15\% of the total, (2) the possibility to pay in pounds sterling, and (3) waiving the advance payment requirement. Plan B aimed for the cooperative development of the collection and the document delivery service of the British Library, as well as the collections of RLUK member libraries (McGrath, 2012). Ultimately, Plan B was not implemented due to the success in obtaining most of the terms of Plan A, which saved RLUK members approximately $f 20$ million (Stachokas, 2018).

In addition, libraries also began to investigate alternative approaches to the big deal model more vigorously. The editorial column published in December 2013 in Serials Review on the possible disappearance of the big deal (Boissy et al., 2012) included the opinions of 13 professionals from the world of publishing, university libraries, and their consortia. Although the participants' views on the value of the big deal and its survival or prospects for replacement varied widely, there was general recognition of the financial pressure on libraries to consider other options. Some suggested relying more on alternatives such as interlibrary loans (ILL), pay-per-view, just-in-time purchases, and smaller packages or title-by-title subscriptions. Others were in favor of open-access options, driven by practical concerns about prices, but also for reasons of equity and access to information. Most, however, agreed that the big deal was still a functional reality for many libraries and consortia (Stachokas,2018).

However, since the Great Recession, libraries have increasingly used other procurement systems for electronic resources, in addition to big deals: patron-driven acquisition (PDA or demand-driven acquisition, DDA), evidence-based acquisition (EBA), which are models based on the effective use of resources by users, or pay-per-view (PPV), which allows libraries to purchase individual articles from a publisher's collection (Weicher; Zhang, 2012). Just-in-time acquisitions allow an electronic resource to be served immediately upon user request. Users can browse resources and verify that they really need a specific title before the library has to pay its full cost. When combined with ILL services, such just-intime purchases can be cost-efficient alternatives for sharing resources between libraries (Ward, 2014).

In Spain, it is surprising that the 2008 crisis did not lead libraries and their consortia to take drastic measures regarding their subscriptions to the main big deals. Some consortia did limit their subscription to titles, but the main cuts that libraries had to make impacted more on staff or on expenses on their collection outside the big deals. Simón-Martín, Arias-Coello, and Simón-Blas (2016) point out that, between 2008 and 2014, spending on electronic resources by libraries and library consortia increased at the expense of spending on monographs and paper-based journals, a situation like that experienced by American universities.

\subsection{The need to evaluate big deals}

Assessing the gains or losses that big deal contracts entail is a complex task. As Reader (1999) pointed out and as subsequently confirmed by the analysis carried out within the framework of Nesli2 (UK National electronic site licensing initiative 2) (Conyers; Dalton, 2007), comparative measures of the profit obtained from the big deal model are difficult to carry out for several reasons:

- The different starting situations of the collections of each institution.

- The specific terms of each contract.

- The different strategies used for the development of digital collections.

The value of big deals cannot be considered solely in financial terms; rather, it is also necessary to take into account their effect on teaching and research in the university community. According to Tenopir and King (2000), the main purpose of $75 \%$ of the use of electronic publications is to carry out research activity, while $41 \%$ is linked to teaching.

As Sjoberg (2017) indicates, libraries use several common criteria when evaluating electronic journals. These include prices and inflation, usage statistics, cost per use, overlap analysis, and the opinion of specialists in the field. Along with these main criteria, additional factors are mentioned, including citation analysis, impact factor, concentration of use, ILL data, the adaptation of resources to teaching programs, and publisher reputation. Recently, Mongeon et al. (2021) found that all indicators have limitations and should thus be treated as complementary. Using a combination of methods will likely provide better results. Here are some examples of the evaluation of big deals in the period following the Great Recession of 2008 (Stachokas, 2018): 
lowa State University (ISU) used an evaluation model based on cost per use and ILL costs to evaluate the Springer and Wiley big deals (Pedersen; Arcand; Forbis, 2014). Library staff began collecting data in 2010 to prepare for the 2012 Springer package renewal. Those titles with a cost per use greater than US\$17.50, a figure taken from a study on the cost of ILL carried out by ARL in 2003, were selected by the acquisitions department as candidates for cancellation, after consulting with subject librarians. The subscriptions to some of these titles, particularly those with a high impact factor, were renewed by the library, indicating the value of the use of this metric in conjunction with other data to evaluate journals that staff planned to consider for future cancellations. A limited increase in ILL activity was observed afterwards. In 2014, the ISU library applied the lessons learned, in this case to the renewal of their big deal with Wiley. Drawing on their experience at ISU, Pedersen, Arcand, and Forbis (2014) recommended that libraries calculate the cost per use of all the big deals at their universities to compare them with each other. They also advised libraries to gather local ILL data, consult with subject-matter specialists on specific titles, clearly document all criteria used in journal evaluation, monitor the consequences of cancellations in the future (including ILL activity), establish a fund to acquire titles that are in great demand through ILL, and create a system to identify journals that are not being used at the level expected of an active subscription.

Some institutions have adopted an even broader approach to the evaluation of big deals. For example, Kansas University (KU) (Rathmel; Currie; Enoch, 2015) used Counter usage statistics, the use of documents from its institutional repository, the Eigenfactor impact index of journals, data from Project Mesur (Measures from Scholarly Usage of Resources), overlaps, altmetrics, email and web/click statistics, discovery software statistics, OpenURL statistics, usability studies, and surveys. $K U$ librarians also developed a formula to estimate the potential cost of ILL for cancelled journals, the annual use of these journals prior to cancellation, an average copyright fee per article of US\$45, and a staff cost of US\$7 per item.

Meanwhile, Scott (2016) calculated a ratio of 17 to 1 of Counter uses with respect to ILL requests, based on the use data of the Elsevier, Springer, and Wiley journals between 2006 and 2008 at the University of Wisconsin-Milwaukee. To evaluate their subscription models, the University of South Alabama (Lemley; Li, 2015) used a comparison of the cost per use of bundled journals versus individual subscriptions by titles, pay-per-view costs, and ILL fees. Duke University, the University of North Carolina at Chapel Hill, and North Carolina State University (Martin et al., 2016) tried to analyze in depth their return on investment using the cost per cited reference variable (CPCR), based on citations in Scopus (assigning a monetary value to each citation to a particular journal by the authors affiliated with the subscribing institution over a period). The use of this metric was intended to reduce the weight of the cost per use (downloads) when analyzing library expenditure on subscriptions, and although the new measure was imperfect, the authors of that study recommended the continuous use of CPCR in the evaluation of collections.

Beyond the US domain, the Canadian Research Knowledge Network (Jurczyk; Jacobs, 2014) applied an algorithm measuring quality, utility, and value to evaluate big deals across multiple institutions and concluded that the packages were beneficial in terms of cost-effectiveness for most member libraries. The data applied included usage, researcher publications, impact factors, source-normalized impact per paper (SNIP), cost per use, and cost per SNIP. Furthermore, the use of multiyear contracts combined with the purchasing power of large regional and national consortia managed to regulate price increases for member libraries.

In the European context, the library of Maastricht University in the Netherlands (Dikboom, 2016) evaluated its big deals and found that they represented a saving of up to $40 \%$ compared with the cost of title-by-title subscriptions when considering various lists of core titles by discipline. The parameters included in that evaluation were: a list of core titles as determined by academic staff, usage statistics, the price list of all journals, the impact factors of the titles, etc.

In 2013, Glasser found that the big deal may or may not be a good deal. An analysis of five big deals conducted by Hofstra University, New York, in 2012 found that most of the contracted packages were a good deal for that university. An important measure of their value was the low cost of use, which ranged from US\$4.59 to US\$9.44 per download. However, what was decisive for the university was that, in all but one case, the cost of subscribing to individual titles with very high usage exceeded the cost of the entire package. Glasser cautioned that, in the case of cancellations, subject librarians and academic staff would have to be consulted, since while metrics are useful, one must be aware of their limitations. Along the same vein, Jones et al. (2013) also warned that quantitative data cannot be the only measure used when it comes to evaluating collections.

Some of the actions mentioned in relation to big deals were probably due to the upheaval caused by the Great Recession and its impact on the financing of higher education, including university libraries. However, for many librarians, the big deal is just another business model that must be evaluated in relation to the needs of local users. A study on contracting of large journal packages between 2002 and 2012 (Strieb; Blixrud, 2014) revealed that the majority of ARL members continued to subscribe to big deals, in the most part negotiated through consortia, although the cost increases were a reason for concern. 


\subsection{First cancellations}

We discuss below some experiences regarding cancellations of big deals. To obtain a complete overview of these initiatives, refer to the Sparc big deal cancellations tracking log:

https://sparcopen.org/our-work/big-dealcancellation-tracking

This includes cancellations of big deals from, among others, the big five publishers: Elsevier, Wiley-Blackwell, Taylor \& Francis, Springer Nature, and SAGE (for social sciences and humanities) and the American Chemical Society (for natural and medical sciences), which collectively control more than $50 \%$ of the journal publishing business (Larivière; Haustein; Mongeon, 2015; Tay, 2019). The first cancellation, by Harvard University with Elsevier, occurred in 2004. This cancellation was followed in time by those of Lafayette College in 2008 and the University of Alabama at Birmingham in 2009, also with Elsevier, and those of the University of Oregon and Southern Illinois University in 2009, with Elsevier and Wiley. Note that, in some cases, these cancellations were enacted by the universities or consortia as a measure to apply pressure and negotiate better prices.

Below we illustrate this process using the example of the latter two universities mentioned above, in addition to other noteworthy cases (Stachokas, 2018). The University of Oregon and Southern Illinois University Carbondale (SIUC) decided to abandon their big deals with Elsevier and Wiley due to the financial impact of the Great Recession. In fact, SIUC also decided to abandon its big deal with Springer. By cancelling these subscriptions, SIUC users lost access to 242 Elsevier titles, 597 Wiley titles, and 1,100 Springer titles. These titles had 40,000 downloads, but Nabe and Fowler (2012) noted that $82 \%$ of the cancelled Springer journals received only one download per month or less. They found that only $27 \%$ of the ILL requests that were made matched cancelled Wiley titles, while only $9 \%$ were requested more than once. In addition, regarding the $25 \%$ of Wiley's most used and cancelled titles, there were only 71 ILL requests, corresponding to titles that had previously had 7,700 downloads. The cancellation of the big deals resulted in annual savings of US\$300,000 and attempts to fine the SIUC by suppliers were prevented through negotiations.

Nabe and Fowler (2012) pointed out that the University of Oregon used a different tactic, replacing its big deal with Elsevier, which it had signed through the Orbis-Cascade Alliance consortium, with an agreement or mini-consortium with the Oregon and Portland State Universities that was based on a shared list of titles. The savings were lower than those obtained by the SIUC but sufficient to stabilize the collections spending budget because, in addition, there were cuts in Wiley subscriptions. Academics in the areas of physics and chemistry were the most concerned about this change, but pay-per-view services were provided as a complement to ILL in these fields. Wiley's big deal was cancelled and replaced by title-by-title subscriptions to 297 journals.

Years later, Nabe and Fowler (2015) found that their institutions continued to benefit from the measures taken between 2008 and 2010. Both universities stated that the impact on ILL requests was limited and that they were satisfied with the budget savings achieved. Such a low impact of cancellations on ILL has also been noted on other occasions, as seen at lowa State University (Pedersen; Arcand; Forbis, 2014).

Jones, Marshall, and Purtree (2013) reported a less positive experience when they cancelled the Wiley-Blackwell and Springer packages at Mississippi State University (MSU). Under time pressure and needing to reduce the budget by US\$500,000 in fiscal year 2012, MSU librarians relied almost exclusively on usage statistics. Access to 2,800 journals was lost, with a disproportionate impact on some disciplines, particularly in the social sciences. They thus confirmed the need to gather qualitative as well as quantitative information before selecting titles for cancellation, especially the opinion of subject librarians and academics who were teaching and conducting research on campus.

As pointed out by Machovec (2014) of the Colorado Alliance, big deals are still very attractive for libraries and thus difficult to cancel. However, Machovec asked publishers and other intermediaries to accept more standard terms and conditions, such as the right to use ILLs without having to resort to additional negotiations, but above all greater flexibility in the configuration of packages and the ability to secure group discounts even if some libraries choose other options.
Questioning of the big deal model began early in the USA, and the beginning of the Great Recession in 2008 drove this process and promoted the search for alternatives. In Spain, it is surprising that the 2008 crisis did not lead libraries and their consortia to take drastic measures regarding their subscriptions to the main big deals 
A conversation about the big deal with five librarians well versed in this model was reported by Ruschoff (2014), who concluded that the big deal was far from dead but that its role in the information market was probably subject to change, given the emergence of more open-access titles, the HathiTrust initiative, and other coalitions. Likewise, it was concluded that a dialog between editors and librarians was necessary to identify more viable models. In particular, one of the executives, Anderson (2006), questioned the long-term viability of the big deal, given that the materials acquisition budgets of most libraries were frozen and that they could not cope with even modest annual cost increases.

\section{Big deals in the face of the advance of open access: cancellations and transformative agreements}

Open access is sometimes cited as the definitive answer to the problem of the increasing costs of scientific journals for academic libraries. Changes in the scientific communication system and the increase in open-access publications have been constant phenomena over the last two decades (Severin et al., 2018; Piwowar et al., 2018; Lewis, 2012), which has led to a deep reflection on subscription models and access to scientific information. Such access is undergoing a profound transformation due to the emergence of new channels for the dissemination of research work such as $R e$ searchGate (Meier; Tunger, 2018) and Sci-Hub (Himmelstein, 2018), and above all the consolidation of the open-access movement and national and European policies aimed at guaranteeing that research results paid for with public funds are published openly (Borrego; Anglada, 2016; Jamali; Nabavi, 2015).

\subsection{Questioning the big deal model: new cancellations}

In response to a post on Scholarly Kitchen (Russell, 2019), Melissa Belvadi (University of Prince Edward Island, Canada) pointed out that, although there have been many cancellations of big deals due to budgetary constraints, this trend has not been due to the presence of open-access content in the packages. This leads to the question of the percentage of big deals journals that must be open access before libraries consider cancelling them. It is highlighted that, with Counter CoP5, which began to be used by most publishers in January 2019, data are already being obtained on what proportion of the use of big deals corresponds to open-access content, whether that be open access journals or hybrid journals, and perhaps librarians will begin to study such percentage data to consider the attractiveness of subscribing to big deals. In the same post, David Crotty (a consultant at Clarke \& Esposito) asserts that a growing number of librarians are using Unpaywall data in their negotiations with publishers and asking why they must continue paying for open-source material.

Thus, in recent times, some countries and regions have chosen to abandon journal subscriptions via some big deals, convinced that they are not as attractive as they once were because much of the content is available via open access while other content can be accessed through various platforms. In this regard, Gardner and Inger (2018) confirm that, in the richest countries, articles are accessed through free resources $60 \%$ of the time, compared with $70 \%$ in countries with less resources. Schonfeld (2019) pointed out that mature markets exhibit a decrease in the number of downloads provided by providers due to access leakage to other platforms. In fact, publishers are trying to stop this by resorting to content syndication, as in the case of the pilot agreement between Springer Nature and ResearchGate (Hinchliffe, 2019c; Hinchliffe; Schonfeld, 2019; Springer Nature, 2019). Another trend is the transformation of traditional big deal contracts into others that include paying for publishing in the open, as described below.

If, as mentioned above, budget cuts deriving from the impact of the Great Recession were the determining factor for cancellations in the years following 2008, in recent years they have been linked to the advance of open science and the need to negotiate not only read access but also open publishing costs.

The first and most famous cases correspond to the situation experienced in Sweden, Germany, and California after the first cancellation of the Elsevier big deal at the end of the last decade. During the negotiations with these universities, Elsevier argued that the number of subscribed articles published grew more than its proposed price increase, resulting in a decrease in the cost of each article. It also pointed out that usage continued to increase, thus decreasing the cost of each downloaded item. However, in the eyes of European and American libraries, the value of the big deal had declined, as already indicated above (Schonfeld, 2019). This perception conditioned the negotiations, since Elsevier no longer had the same power as in previous times to fix the prices.

In spring 2018, the Swedish library consortium Bibsam, managed by the National Library of Sweden on behalf of the universities and other scientific and government bodies, decided to cancel their subscription with Elsevier. This was the first time that the members of the consortium had faced such a situation (Olsson et al., 2020a).
In recent times, some countries and regions have chosen to abandon journal subscriptions via some big deals, convinced that they are not as profitable as they once were because much of the content is available via open access while other content can be accessed through various platforms 
Although the Swedes retained access to publications from before the cancellation, the same did not occur regarding access to documents published after the cancellation date of 1 July 2018. Some research fields suffered more than others from the impact of this cancellation, specifically those with a less well-developed open-access publishing culture and greater obsolescence -due to the embargo period. The cancellation forced investigators to adjust to the circumstances. They had to spend more time searching for articles and generally did not visit libraries to request articles that they did not have access to. This circumstance has been verified by quantitative data showing that requests for library services did not increase as feared (Olsson et al., 2020b). The results of a survey carried out to determine the opinion of researchers regarding this cancellation highlighted the disparity of opinions about it. The argument in favor of the break with Elsevier was a desire to change the scientific communication system and move towards open access. The most common argument against was the harm caused to research and researchers by not being able to access certain resources (Olsson et al., 2020a).

Shortly after the Swedish libraries abandoned their negotiations with Elsevier, the publisher also cut access to its content to German libraries for the same reason, i.e., differences regarding the cost of a national open-access agreement (Else, 2018). Faced with the situation created by this cancellation, the reaction of researchers was less negative towards the new situation than expected, for several reasons (Tay, 2019): firstly, the fact that many institutions had perpetual access to journals and were thus still able to access pre-cancellation content, and secondly, the availability of extensive ILL networks and document delivery services. In Germany, at least one institution retained access to Elsevier and provided access to ScienceDirect content to other universities. However, it appears that the number of ILLs and document delivery service transactions did not increase as much as expected, indicating that academics were gaining access in other ways.

The University of California's 2018-2019 negotiation with Elsevier was followed with great interest. In February 2019, a press release stated that Elsevier was unwilling to comply with the University of California's goals of ensuring universal open access to the university's research and to limit escalating costs. After its relationship with Elsevier ended, the University of California tried to ensure that it provided alternative forms of access to its researchers. Most of these alternatives were instruments and repositories designed to access content through green road open access. As in the German case, ILL and document delivery services were also offered as alternatives. Since the use of ILL involves costs for not only the borrower but also the lender, this situation caused concern among other libraries considering that, if other consortia followed the example of the University of California, the situation of libraries with subscriptions to an Elsevier package could become unsustainable.

For urgent content needs, the University of California offered the use of a document delivery service through its provider Research Solutions/Reprints Desk:

http://researchsolutions.com

The user could request an article directly or through the library, and the system provided them with immediate access. The library paid for the service, and the provider passed on part of the payment to the publisher. The service could be configured in such a way that it replicated the access mode to the content of the big deal and, therefore, did not cause user inconvenience (Schonfeld, 2019). However, both the ILL and the document delivery service could lead to significant costs to the library if demand increased dramatically, as might be expected after a large cancellation. Although demand for these services might not be very high initially as access to the pre-cancellation collection was retained, it was forecast that demand would grow over time and that the University of California would have to make decisions in this regard. However, this scenario did not finally materialize because, in 2020, both parties signed a transitional agreement, and on 16 March 2021 it was announced that the University of California had renewed their subscription to Elsevier's big deal, representing the largest transformative agreement in North America (Hinchlife, 2021).

However, Elsevier was not the only publisher to be affected by such cancellations. This situation of breaking relations also occurred in France with Springer, and in February 2018, the Canadian Association of Research Libraries published a report that described subscription costs as unsustainable and demanded a coordinated national approach against increasing journal prices (Kwon, 2018).
The cancellation forced investigators to adjust to the circumstances. They had to spend more time searching for articles and generally did not visit libraries to request articles that they did not have access to 


\subsection{The first transformative deals: the revision of the big deal}

cOAlition S released its Plan S on 4 September 2018. Its preamble mentioned that the involvement of universities and libraries in negotiations with large publishing houses is essential to progress with the elimination of economic barriers to science. It stipulates that transformative agreements, where subscription costs are offset by publication costs, can help to accelerate the transition to open access. It specifies that there must be total transparency in such agreements and that their terms and conditions must be publicly known (Schiltz, 2018).

Transformative agreements aimed at open access are defined by the Efficiency and Standards for Article Charges (ESAC) initiative as contracts negotiated between institutions (libraries and national or regional consortia) and publishers that transform the business model of the publication of scientific journals from a subscription-based access system to one in which publishers are paid a fair price for their open-access publishing services:

ESAC guidelines for transformative agreements

https://esac-initiative.org/about/transformative-agreements

As noted by Gruenpeter et al. (2021), this change is irreversible and implies both financial and operational transformations. In short, the aim of transformative agreements is to change pay-for-reading to pay-for-publishing, and that this change is cost free, since there is sufficient money in the system to allow the business model to change and for institutions to pay publishers to publish their authors' articles in open access instead of paying for access to read subscribed content.

Massachusetts Institute of Technology (MIT) (2019) has established a framework to guide negotiations with academic publishers toward more open and inclusive science. One of the principles established is that institutions will pay a fair and sustainable price to publishers for value-added services, based on transparent and cost-based pricing models, according to the cOAlition $S$ guidelines.

The University of California (2019) distinguishes several types of agreements that represent steps in this evolution towards open access: offsetting agreements, read and publish agreements, and publish and read agreements.

- In an offsetting agreement, subscription and publication costs are offset such that either subscription payments are reduced as publication costs increase or article processing charges (APCs) are subtracted from subscription costs.

- In a read and publish (RAP) agreement, often a single fee covers both access to the subscribed content as well as open-access publication for authors affiliated with the institution, with the balance tipped towards subscription charges.

- In a publish and read (PAR) agreement, all or most of the cost depends on the articles published in open access, with read access and rights to perpetual access to subscribed articles included as a benefit of the agreement.

Borrego, Anglada, and Abadal (2020) highlight that transformative agreements are more transparent than traditional licenses for contracting big deals since they allow authors to retain copyright and make provisions to facilitate the management of open-access flows.

Morais, Bauer, and Borrell-Damián (2018) collected data on European big deals through a survey and pointed out that, although it was not yet common in 2016-2017 for contracts to include APCs in big deal negotiations (11\%), $63 \%$ of respondents intended to include them in subsequent negotiations. In a report one year later, that collected data from the survey carried out between 2017 and 2018 (Morais; Stoy; Borrell-Damián, 2019), APCs were already included in $19 \%$ of cases and $65 \%$ of consortia

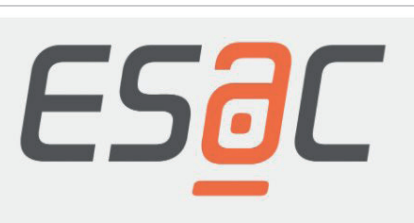

NEWS MARKETWATCH TRANSFORMATIVEAGREEMENTS DATAANALTICS WORKFLOWS MORE RESOURCES TRANSFORMATIVE AGREEMENTS What are transformative agreements? "Transformative agreement" is an umbrella term describing those agreements pegotiated between instiutions ilibranes, national and regicnal consortia) and publishers in which hom scholarly jurnal publishing gradually and detintively shitting trom one based on toll access (subscintion) to one in which publishers are remunerated a fair price for their open access publishing services

ESAC guidelines for transformative agreements https://esac-initiative.org/about/transformative-agreements

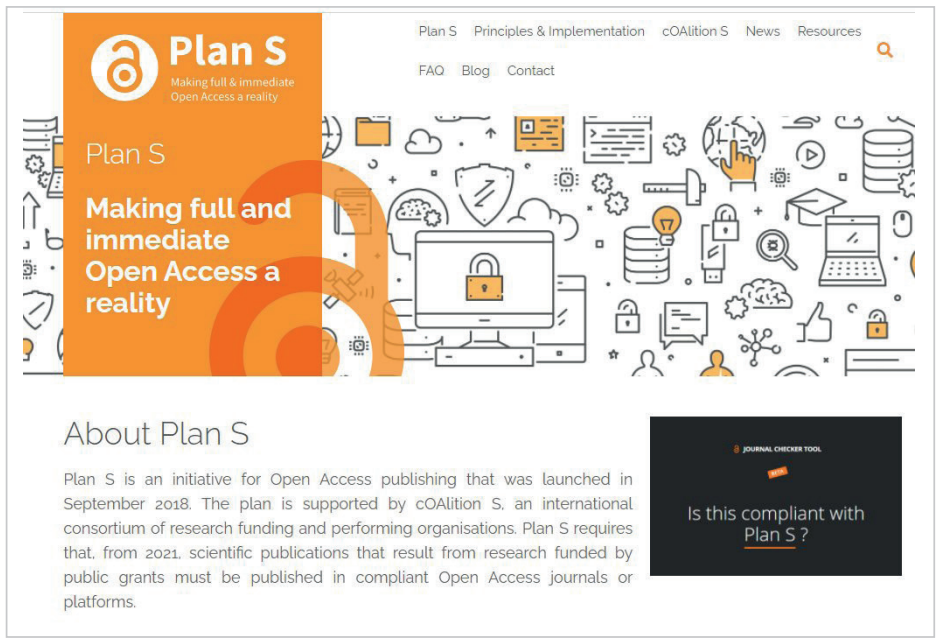

https://www.coalition-s.org 
were in favor of a single contract including both APCs and subscription fees. Looking at APCs by publisher, Springer and Elsevier had the highest percentage of contracts that included APCs, at $14 \%$ and $12 \%$, respectively. Approximately $20 \%$ of contracts with Taylor \& Francis included offsetting clauses.

To date, such transformative agreements have remained a European phenomenon, possibly due to the momentum that COAlition $S$ and its Plan $S$ have provided to open science. In fact, the ESAC registry (ESAC Transformative Agreement Registry) does not mention any transformative agreements in the USA beyond those of Florida, Carnegie Mellon, and California State University:

https://esac-initiative.org/about/transformative-agreements/agreement-registry

If the University of California's negotiation with Elsevier generated great interest, this was no less so regarding the transformative agreement it reached in April 2019 with Cambridge University Press, the first agreement of its kind for the university and for the publisher. Also in 2019, Carnegie Mellon University announced that it had signed a transformative agreement with Elsevier, the first between this publisher and a US university. In early 2020, several institutions reported negotiations or new agreements with publishers, such as that mentioned above between the University of California and Elsevier. However, MIT and the University of New York library consortium did not reach an agreement, and in parallel, the University of North Carolina at Chapel Hill and lowa State University also decided to cancel their big deals with Elsevier.

The negotiations and agreements of European countries with content providers reveal that the 31 European consortia distribute their expenditure as follows: Elsevier (56\%), Wiley (18\%), Springer (16\%), and Taylor \& Francis (7\%) (Morais; Stoy; Borrell-Damián, 2019).

According to Gruenpeter et al. (2021), in Germany, the Rektorenkonferenz (Conference of Rectors) was commissioned by the Allianz der deutschen Wissenschaftsorganisationen (Alliance of German Science Organizations) to establish Projekt $D E A L$, which is responsible for negotiating transformative agreements with the three largest academic journal publishers: Wiley, Springer Nature, and Elsevier. The objectives of these negotiations included: providing immediate open access to all new articles by authors from German institutions, ensuring permanent open access to the full texts of the publishers' portfolio of journals, and establishing a fair and reasonable price for the services of each publisher. The first agreement was reached with Wiley (2019-2021), while the agreement with Springer covers the period 2020-2022. However, no agreement was reached with Elsevier in 2018, and almost 200 German universities and research institutions no longer had access to new ScienceDirect content after 2019. On the contrary, the Hungarian consortium EISZ signed an agreement with Elsevier for three years in 2019. In addition to accessing ScienceDirect, researchers affiliated with EISZ can publish their research in open access without having to pay APCs.

Negotiations also take place at the national level in Norway, and in 2020 several agreements were reached with publishers, including those signed with Springer Nature and Taylor \& Francis, both for three years (2020-2022). The pilot agreement with Elsevier, which ended in December 2020, has been renewed for another year, and that signed with Wiley ends at the end of 2021. In Sweden, negotiations with providers are conducted by Bibsam, the consortium of Swedish libraries. The main objectives of the negotiations are:

- To obtain immediate open access to all articles published by the publisher for all researchers affiliated with participating organizations

- To obtain access to read the content of all the publisher's journals for all the participating organizations

- To institute a sustainable pricing model that allows a transition to open access

In 2020, a three-year agreement was reached with both Elsevier and Wiley, while two agreements had previously been signed with Springer.
The idea of transformative agreements is to change pay-for-reading to pay-for-publishing, and that this change is cost free, since there is sufficient money in the system to allow the business model to change and for institutions to pay publishers to publish the articles by their authors in open access instead of paying for access to read the subscribed content 
In Finland, the negotiations are led by FinE$\mathrm{Lib}$, the consortium that operates from the National Library. Agreements have been reached most recently (2020) with Wiley, Taylor \& Francis, the IEEE/IET Electronic Library, and SAGE. The existing Elsevier agreement that ended in December 2020 has been renewed for three more years. In the case of the United Kingdom, transformative agreements are negotiated by JISC Collections. After reaching a first agreement with Springer Nature (2019-2021), JISC Collections began negotiations to secure agreements with all the major publishers. Thus, in 2020, it signed one for four years with Wiley and another for three years with $S A G E$, among others.

Transformative agreements have also been signed in other countries, such as Austria, Switzerland, and the Netherlands (Gruenpeter et al., 2021). In Spain, the Higher Council for Scientific Research (CSIC) has signed three transformative agreements, with Cambridge University Press and Oxford University Press in 2020, and with the Microbiology Society in 2021. Similarly, the Universitat de Barcelona recently reached an agreement with Cambridge University Press, as recorded in the ESAC Transformative Agreement Registry.

At the end of 2020, the research vice-rectorships of the Spanish universities reported on the negotiations between the Conference of Rectors of Spanish Universities (CRUE)-CSIC and four of the most powerful publishers (ACS, Elsevier, Springer, and Wiley) to establish transformative agreements. Those negotiations, which are part of the objective of promoting a new open science environment in Spain, seek to replace the current pay-to-read model with one of pay-to-read and pay-to-publish in open access the works of authors of the Spanish universities affiliated to the CRUE and CSIC, which corresponds to more than $90 \%$ of the scientific research produced in Spain. As a result of these contacts, on 25 March 2021, the CRUE and CSIC signed a transformative agreement with Elsevier, the first of its kind at the national level:

https://www.crue.org/2021/03/convenio-crue-csic-eselvier

Shortly thereafter, on 14 April, they also signed an agreement with Wiley to promote an increase in open-access publications, as a result of which it is estimated that $70 \%$ of the articles published by participating institutions in 2021 will be open access:

https://www.crue.org/2021/04/crue-csic-wiley-acuerdo-acceso-abierto-en-espana

In this case, this is only a pilot agreement for 2021, to provide both parties with time to continue negotiating an agreement for subsequent years (2022-2024). Finally, on 5 May, the CRUE and CSIC reached an agreement with the publisher Springer that will allow universities linked to CRUE and CSIC to publish OA in more than 2,300 Springer Nature titles, remaining valid until December 2024:

https://group.springernature.com/gp/group/media/press-releases/springer-nature-leads-drive-for-oa--spain/19134258

Gruenpeter et al. (2021) highlight the importance of negotiating prior to signing transformative agreements. They recommend analyzing data on the journals that are most popular among authors, the publisher's market share, the history of payments to the same publisher, authors' preference for open access, the use of the journals, citations, etc. Having well-defined objectives is a necessary starting point for negotiations and must be agreed upon by all stakeholders. The growing number of open science policies being adopted by scientific institutions, funders, and governments makes it essential to fit transformative agreements into the context of these policies and to ensure that they are an instrument for their implementation and fit into this strategy in the long term. 
Transformative agreements with the same publishers have been negotiated and signed in numerous countries. Negotiators must thus be aware of the situation in other settings and use the information available thanks to the transparency of transformative agreements that have already been signed. Attention must also be paid to the practicalities of the negotiations so that tactical errors do not compromise the results. In this regard, a toolkit detailing the negotiations carried out by the University of California (2019) has made available to anyone who is interested. Likewise, all stages of the negotiation must be accompanied by communication activities based on a wellconsidered and flexible strategy aimed at both academia and the general public, who have to understand the process and its results in the context of shared principles and values and aimed at the common good (Emery; Stone, 2013; Gruenpeter et al., 2021).

\section{Final considerations}

Facilitating the discovery of high-quality, freely available electronic resources is an essential cost-containment strategy for university libraries. When free information resources that meet the needs of users and that are easily accessible and usable are available, it makes no sense to pay for duplicate content. As highlighted above, the availability of content through repositories and academic networks (not forgetting the pirate platform Sci-Hub) has led to a decrease in the perceived value of big deals and supported negotiations and cancellations of big deals by university libraries (Andersen, 2019). If much content is accessible from outside of publisher packages, the cost of each download increases. To limit costs in the establishment of the collection, the challenge is to identify the most economical way to obtain the most content with the fewest access restrictions, considering both ownership and perpetual access (Wenzler, 2017).

As Stachokas (2018) points out, libraries have approached this problem in recent years by using a wide variety of methods, ranging from big deals to patron-driven acquisition (PDA), demand-driven acquisition (DDA), and evidence-based acquisition (EBA), unbundling and cancellation projects, open access and use of freely available electronic resources, as well as smaller-scale agreements with vendors and those that are more tailored to customer needs. Choosing the correct method in each case requires a comprehensive and complex analysis of the collection, as well as an understanding of the mission and ever-evolving strategy of the institution that the library serves. The successful application of these business models also requires that librarians learn professional techniques and good practices from the business world, particularly when it comes to price negotiation and the complex terms of vendor licenses. While a university library cannot and should not be run like a business, librarians must be able to reach good deals in order to make the development of electronic collections financially sustainable in the long term.

The well-known situation of the different costs of big deals and the variety of conditions in transformative agreements lead one to consider whether such negotiations, which have most often gone beyond the regional level to be carried out at the national level, should not in fact be carried out in an even more global fashion, to achieve a more efficient, fair, transparent, sustainable, and open academic publishing system.

Authors who describe the post-cancellation period speak of a more positive result when users are involved in decision-making (Enoch; Harker, 2015; Foudy; McManus, 2005), highlighting the importance of a good communication process. Regarding the cancellation of the Elsevier big deal in Sweden, researchers had a lack of knowledge about the role of higher-education institutions, libraries, and consortia in open-access license negotiations. Indeed, it was this ignorance that caused researchers to question whether they had been represented well in the negotiations (Olsson et al., 2020a).

Although big deals and open access have grown separately, they now go hand in hand thanks to transformative agreements that must be considered as a transition stage to end the subscription model and achieve a sustainable, open scientific communication system for all stakeholders that allows researchers to publish in their journal of choice (Van-Barneveld-Biesma et al., 2020; Björk, 2021). Transformative agreements have advantages, including increased open-access publication, improved flows in the process of publication, and simplified management for researchers. Likewise, the conditions of such agreements are openly available, representing a substantial improvement over the contracts of the traditional big deals. Likewise, they eliminate "double dipping" or double payment for both reading and publishing. Besides, the introduction of APCs into agreements along with fees for reading results in greater clarity of invoices. However, they also have drawbacks: they perpetuate the system and its high costs (Lawson, 2019). We want to point out that the term "big deal" is no longer present in these agreements.

Publishing by paying APCs is a business model for funding open-access publications. This fee can be paid by the author, their institution, or the research funding
Although big deals and open access have grown separately, they now go hand in hand thanks to transformative agreements that must be considered as a transition stage to end the subscription model and build a sustainable, open scientific communication system 
body. As Tay (2019) points out, if libraries become intermediaries in the payment of APCs for articles published by their institutions, they will secure a role in the coming world that will be dominated by open access. This change will also affect consortia (Hinchcliffe, 2019a; 2019b): previously, the criteria for sharing the cost of big deals were generally based (once the determining factor for paper subscriptions had been settled) on the size of the institutions as measured by their number of full-time academics. If the cost of agreements is now to be based on payments for publishing, the productivity of each institution will become the main cost distribution criterion. Esposito (2018) argues that the move towards open access may make less research-oriented institutions feel the temptation to cancel their subscriptions, and if this happens within a consortium, the balance of cost sharing may be disrupted.

On the other hand, if the transformation towards open access is consolidated and spread globally, institutions with a low research profile will have an easier time cancelling big deals, since they will no longer be considered so necessary. As Tay (2019) points out, publishers will logically be uneasy about this prediction. Hence, albeit belatedly and reluctantly, they are agreeing to introduce the publication variable into traditional big deal contracts. This is the way to ensure the fidelity of research institutions.

The current pandemic was not foreseen, and we do not yet know its scope nor its impact on the world of scientific information. It can be foreseen, however, that many libraries may not be able to sustain their big deals, let alone replace them with even more expensive, transformative deals. The situation created by Covid may thus make it difficult to sustain this model, again leading to requests for flexibility (Icolc, 2020) and to avoid price increases (consortia and Spanish purchasing groups, Rebiun and CSIC, 2020). Based on the 2019 Ithaka S+R US Library Survey, Frederick and Wolff-Eisenberg (2019) report that half of the American library directors surveyed before the pandemic were likely to cancel some of the main big deals while few indicated that they planned a replacement with a transformative deal. The survey carried out by Ohler et al. (2020) obtained similar results.

In any case, the experiences collated herein suggest that cancellations have had less negative consequences than expected. They do not impact to the expected extent on ILLs and document delivery services (Knowlton; Kristanciuk; Jabaily, 2015; Ohler et al., 2019). As pointed out by various authors, the reading time of researchers is limited and the range of open-access resources wide.

\section{References}

Anderson, Chris (2006). The long tail: Why the future of business is selling less of more. New York: Hyperion Books. ISBN: 978140130237

http://dl.motamem.org/long_tail_chris_anderson_motamem_org.pdf

Anderson, Rick (2019). "They know we know they know: Does Sci-Hub affect library suscriptions?". The Scholarly Kitchen, July 3.

https://scholarlykitchen.sspnet.org/2019/07/03/they-know-we-know-they-know-does-sci-hub-affect-library-subscriptions

Anglada, Lluís (2003). "Impacto e influencia de los consorcios en la gestión de las colecciones”. BiD: textos universitaris de biblioteconomía i documentació, n. 10.

https://bid.ub.edu/10anglada2.htm

Baker, David (2008). "Inside every fat man. Balancing the digital library budget". Interlending and document supply, v. 36 , n. 4, pp. 213-217.

https://doi.org/10.1108/02641610810919561

Ball, David (2004). "What's the "big deal”, and why is it a bad deal for universities?". Interlending and document supply, v. 32, n. 2, pp. 117-125.

https://doi.org/10.1108/02641610410538586

Bergstrom, Theodore C.; Courant, Paul N.; McAfee, Preston R.; Williams, Michael A. (2014). "Evaluating big deal journal bundles". Proceedings of the National Academy of Sciences of the United States of America, v. 111, n. 26, pp. 9425-9430. https://doi.org/10.1073/pnas.1403006111

Björk, Bo-Christer (2021). "Why is access to the scholarly journal literature so expensive?". Portal: Libraries and the academy, v. 21, n. 2, pp. 177-192.

https://preprint.press.jhu.edu/portal/sites/ajm/files/21.2editorial.pdf 
Blecic, Deborah D.; Wiberley, Stephen E.; Fiscella, Joan B.; Bahnmaier-Blaszczak, Sara; Lowery, Rebecca (2013). “Deal or no deal? Evaluating big deals and their journals". College \& Research libraries, v. 74, n. 2, pp. 178-193.

https://doi.org/10.5860/crl-300

Boissy, Robert W.; Taylor, Thomas N.; Stamison, Christine M.; Henderson, Kittie S.; Okerson, Ann; Van Rennes, Ron; Dooley, Jim; Kemp, Rebecca; Little, Geoffrey; Fowler, David C.; Douglas, Kimberly; Clemens, Lawrence; Linosky, Alexis D. (2012). "Is the big deal dying?". Serials review, v. 38, pp. 36-45. https://doi.org/10.1080/00987913.2012.10765417

Borrego, Ángel (dir.) (2005). Estudi d'usuaris de les revistes electroniques del CBUC. Consorci de Biblioteques Universitàries de Catalunya.

https://www.recercat.cat/bitstream/handle/2072/1439/ESTUDI\%20USUARIS.pdf

Borrego, Ángel; Anglada, Lluís (2016). "Faculty information behaviour in the electronic environment Attitudes towards searching, publishing and libraries". New library world, v. 117, n. 12, pp. 173-185.

https://doi.org/10.1108/NLW-11-2015-0089

Borrego, Ángel; Anglada, Lluís; Abadal, Ernest (2020). "Transformative agrements: do they pave the way to open access?". Learned publishing, v. 34, n. 2, pp. 216-232.

https://doi.org/10.1002/leap.1347

Boukacem-Zeghmouri, Chèrifa; Bador, Pascal; Lafouge, Thierry; Prost, Hélène (2016). "Relationships between consumption, publication and impact in French universities in a value perspective: a bibliometric analysis". Scientometrics, v. 106, n. 1, pp. 263-280.

https://doi.org/10.1007/s11192-015-1779-z

Boukacem-Zeghmouri, Chèrifa; Schöpfel, Joachim (2008). "On the usage of e-journals in French universities". Serials: The journal for the serials community, v. 21, n. 2, pp. 121-126.

https://doi.org/10.1629/21121

Britten, William A. (1990). "A use statistic for collection management: The 80/20 rule revisited". Library acquisitions: Practice and theory, v. 14, n. 2, pp. 183-189.

https://doi.org/10.1016/0364-6408(90)90061-X

Ciber (2009). E-journals: their use, value and impact. Centre for Information Behaviour and the Evaluation of Research (Ciber). London: City University.

http://www.rin.ac.uk/system/files/attachments/E-journals-report.pdf

Consorcios; Grupos de compra españoles; Rebiun; CSIC (2020). Declaración conjunta para el mantenimiento de las colecciones de información científica ante el desafío presupuestario en la crisis Covid-19.

https://www.rebiun.org/noticias/2020/declaracion-conjunta-de-la-mesa-de-consorcios-grupos-de-compra-espanoles-rebiun-y

Conyers, Angela; Dalton, Peter (2007). "Electronic resource measurement: Linking research to practice". The library quarterly: Information, community, policy, v. 77, n. 4, pp. 463-470.

https://doi.org/10.1086/521087

Dempsey, Lorcan (2006). "Libraries and the long tail: Some thougths about libraries in a network age". D-lib magazine, v. 12 , n. 4.

http://www.dlib.org/dlib/april06/dempsey/04dempsey.html

Dikboom, Monique (2016). "Tackling big deals: The experience of Maastricht University". Interlending \& document supply, v. 44, n. 3, pp. 93-96.

https://doi.org/10.1108/ILDS-02-2016-0008

Else, Holly (2018). "Mega-publisher cuts off German scientists”. Nature, v. 559, n. 7715, pp. 454-455. https://media.nature.com/original/magazine-assets/d41586-018-05754-1/d41586-018-05754-1.pdf

Emery, Jill; Stone, Graham (2013). “Chapter 7: Cancellation and replacement review”. Library technology reports, v. 49, n. 2, pp. 35-38.

https://www.journals.ala.org/index.php/Itr/article/view/4738/5647

Emrani, Ebrahim; Moradi-Salari, Amin; Jamali, Hamid R. (2010). “Usage data, e-journal selection, and negotiations: An Iranian consortium experience". Serials review, v. 36, n. 2, pp. 86-92.

https://doi.org/10.1080/00987913.2010.10765289

Enoch, Todd; Harker, Karen R. (2015). "Planning for the budget-ocalypse: The evolution of a serials/ER cancellation methodology". The serials librarian, v. 68, n. 1-4, pp. 96-105.

https://doi.org/10.1080/0361526X.2015.1025657 
Esposito, Joseph (2018). "Counting the holes in the Swiss cheese. 'Read and publish' discovers America”. The scholarly kitchen, 20 June.

https://scholarlykitchen.sspnet.org/2018/06/20/counting-holes-swiss-cheese-read-publish-discovers-america

European Commission (2006). Study on the economic and technical evolution of the scientific publication market in Europe.

https://bit.ly/3jW2rnM

Evans, Paul; Anglada, Lluís; Borrego, Ángel; Peters, J. (2005). "Big deal usage: a case study with Emerald Fulltext”. Library + information update, v. 4, n. 11, pp. 30-33.

Fernández-Ramos, Andrés; Rodríguez-Bravo, Blanca; Alvite-Díez, María-Luisa; Santos-De-Paz, Lourdes; Morán-Suárez, María-Antonia; Gallego-Lorenzo, Josefa; Olea, Isabel (2019). "Evolution of the big deals use in the public universities of the Castile and Leon region, Spain". El profesional de la información, v. 28, n. 6, e280519.

https://doi.org/10.3145/epi.2019.nov.19

Foudy, Gerry; McManus, Alesia (2005). "Using a decision grid process to build consensus in electronic resources canceIlation decisions". Journal of academic librarianship, v. 31, pp. 533-538.

https://doi.org/10.1016/j.acalib.2005.08.005

Franklin, Brinley (2005). "Managing the electronic collection with cost per use data". IFLA journal, v. 31, n. 3, pp. $241-248$. https://doi.org/10.1177/0340035205058809

Frazier, Kenneth (2001a). "The librarians' dilemma. Contemplating the costs of the big deal". D-lib magazine, v. 7, n. 3. http://www.dlib.org/dlib/march01/frazier/03frazier.html

Frazier, Kenneth (2001b). "To the editor: letters in response to the opinion piece, 'The librarians' dilemma. Contemplating the costs of the big deal'". D-lib magazine, v. 7, n. 4.

http://www.dlib.org/dlib/april01/04letters.html\#FRAZIER

Frazier, Kenneth (2005). "What's the big deal?". The serials librarian, v. 48, n. 1-2, pp. 49-59. https://doi.org/10.1300/J123v48n01_06

Frederick, Jennifer K.; Wolff-Eisenberg, Christine (2020). Ithaka S+R US Library Survey 2019. https://doi.org/10.18665/sr.312977

Gardner, Tracy; Inger, Simon (2018). "How readers discover content in scholarly publications: trends in reader behaviour from 2005 to 2018". Renew Publishing Consultants.

https://renewconsultants.com/wp-content/uploads/2018/08/How-Readers-Discover-Content-2018-Published-180903.pdf

Gatten, Jeffrey N.; Sanville, Tom (2004). “An orderly retreat from the big deal: Is it possible for consortia?”. D-lib magazine, v. 10, n. 10.

http://www.dlib.org/dlib/october04/gatten/10gatten.htm/

Glasser, Sarah (2013). "Judging big deals: challenges, outcomes, and advice". Journal of electronic resources librarianship, v. 25, n. 4, pp. 263-276.

https://doi.org/10.1080/1941126X.2013.847672

Gorraiz, Juan; Gumpenberger, Christian; Schlögl, Christian (2014). “Usage versus citation behaviours in four subject areas". Scientometrics, v. 101, n. 2, pp. 1077-1095.

https://doi.org/10.1007/s11192-014-1271-1

Himmelstein, Daniel S.; Rodríguez-Romero, Ariel; Levernier, Jacob G.; Munro, Thomas-Anthony; McLaughlin, StephenReid; Tzovaras, Bastian-Greshake; Greene, Casey S. (2018). "Sci-Hub provides access to nearly all scholarly literature". elife, v. 1, n. 7, e32822.

https://doi.org/10.7554/eLife.32822

Hinchliffe, Lisa-Janicke (2019a). "Transformative agreements: a primer”. The scholarly kitchen, April 23. https://scholarlykitchen.sspnet.org/2019/04/23/transformative-agreements

Hinchliffe, Lisa-Janicke (2019b). “Will transformative agreements unravel library consortia?”. The scholarly kitchen, May 20.

https://scholarlykitchen.sspnet.org/2019/05/20/transformative-agreements-unravel-library-consortia

Hinchliffe, Lisa-Janicke (2019c). "Springer Nature syndicates content to ResearchGate". The scholarly kitchen, March 1. https://scholarlykitchen.sspnet.org/2019/03/01/springer-nature-syndicates-content-to-researchgate

Hinchlife, Lisa-Janicke (2021). "The biggest big deal”. The scholarly kitchen, March 16.

https://scholarlykitchen.sspnet.org/2021/03/16/the-biggest-big-deal 
Hinchliffe, Lisa-Janicke; Schonfeld, Roger C. (2019) "Diverting leakage to the library subscription channel". The scholarly kitchen, July 16.

https://scholarlykitchen.sspnet.org/2019/07/16/diverting-leakage-to-subscription

Icolc: International Coalition of Library Consortia (2010). Statement on the global economic crisis and its Impact on consortial licenses.

https://icolc.net/statement/statement-global-economic-crisis-and-its-impact-consortial-licenses

Icolc: International Coalition of Library Consortia (2020). Statement on the global Covid-19 pandemic and its impact on library services and resources.

https://icolc.net/statement/statement-global-covid-19-pandemic-and-its-impact-library-services-and-resources

Ingenta Institute (2002). "The consortium site licence: is it a sustainable model?". Proceedings of a meeting held on 24th September 2002, London. Oxford: Ingenta Institute. Health information and libraries journal, v. 20, n. 2, pp. $104-107$. https://doi.org/10.1046/j.1471-1842.2003.00421.x

Jamali, Hamid R.; Nabavi, Majid (2015). “Open access and sources of full-text articles in Google Scholar in different subject fields". Scientometrics, v. 105, n. 3, pp. 1635-1651.

https://doi.org/10.1007/s11192-015-1642-2

Johnson, Rob (2019). "From coalition to commons. Plan S and the future of scholarly communication". Insights, v. 32, n. $1,5$.

http://doi.org/10.1629/uksg.453

Jones, Mary-Ann; Marshall; Derek, Purtee, Sharon (2013), "Big deal deconstruction". The serials librarian, v. 64, n. 1-4, pp. 137-140.

https://doi.org/10.1080/0361526X.2013.760389

Jurczyk, Eva; Jacobs, Pamela (2014). "What's the big deal? Collection evaluation at the national level". Portal: Libraries and the academy, v. 14, n. 4, pp. 617-627.

http://hdl.handle.net/10214/8953

Knowlton, Steven A.; Kristanciuk, Iulia; Jabaily, Matthew J. (2015). "Spilling out of the funnel: How reliance upon interlibrary loan affects access to information". Library resources \& technical services, v. 59, n. 1, pp. 4-12.

https://doi.org/10.5860/Irts.59n1.4

Kwon, Diana (2018). "French universities cancel subscriptions to Springer journals". The scientist, March 31. https://www.the-scientist.com/daily-news/french-universities-cancel-subscriptions-to-springer-journals-29882

Larivière, Vincent; Haustein, Stefanie; Mongeon, Philippe (2015). "The oligopoly of academic publishers in the digital era". PLoS one, v. 10, n. 6, e0127502.

https://doi.org/10.1371/journal.pone.0127502

Lawson, Stuart (2019). Evaluating UK offset agreements (2015-17). https://www.napier.ac.uk/ /media/worktribe/output-1911989/evaluating-uk-offset-agreements-(201517).pdf

Lemley, Trey; Li, Jie (2015). “Big deal journal subscription packages: Are they worth the cost?”. The journal of electronic resources librarianship, v. 12, n. 1, pp. 1-10 https://doi.org/10.1080/15424065.2015.1001959

Lewis, David W. (2012). "The inevitability of open access". College \& research libraries, v. 73, n. 5, pp. 493-506. https://doi.org/10.5860/crl-299

Lowry, Charles B. (2011). "Year 2 of the 'Great recession': Surviving the present by building the future". Journal of library administration, v. 51, n. 1, pp. 37-53.

https://doi.org/10.1080/01930826.2011.531640

Machovec, George (2014). "Consortia and the future of the big deal". Journal of library administration, v. 54, n. 7, pp. 629-636.

https://doi.org/10.1080/01930826.2014.964034

Martin, Virginia; Gray, Teddy; Kilb, Megan; Minchew, Tessa (2016). "Analizing consortial big deals via a cost-per-citedreference (CPCR) metric". Serials review, v. 42, n. 4, pp. 293-305.

https://doi.org/10.1080/00987913.2016.1248218

Massachusetts Institute of Technology (MIT) (2019). MIT Framework for publisher contracts.

https://libraries.mit.edu/scholarly/publishing/framework 
McGrath, Mike (2012). "Fighting back against the big deals. A success story from the UK". Interlending \& document supply, v. 40, n. 4, pp. 178-186.

https://doi.org/10.1108/02641611211283831

Meier, Andreas; Tunger, Dirk (2018). "Survey on opinions and usage patterns for the ResearchGate platform". PloS one, v. 13, n. 10, e0204945.

https://doi.org/10.1371/journal.pone.0204945

Mongeon, Philippe; Siler, Kyle; Archambault, Antoine; Sugimoto, Cassidy R.; Larivière, Vincent (2021). "Collection development in the era of big deal". College \& research Libraries, v. 82, n. 2, pp. 219-236.

https://doi.org/10.5860/crl.82.2.219

Morais, Rita; Bauer, Julián; Borrell-Damián, Lidia (2018). EUA big deals survey report: The first mapping of major scientific publishing contracts in Europe. European University Association.

https://eua.eu/resources/publications/321:eua-big-deals-survey-report-the-first-mapping-of-major-scientificpublishing-contracts-in-europe.html

Morais, Rita; Stoy, Lennart; Borrell-Damián, Lidia (2019). 2019 Big deals survey report: An updated mapping of major scholarly publishing contracts in Europe. European University Association.

https://eua.eu/resources/publications/829:2019-big-deals-survey-report.html

Mulliner, Kent (2003). "Implications of electronic journal usage statistics: Conjecture in the OhioLINK environment". In: Bazirjian, R.; Speck, V. (eds.), Charleston conference proceedings 2002. Portsmouth: Libraries Unlimited, pp. 42-51.

Nabe, Jonathan; Fowler, David C. (2012). "Leaving the 'big deal': Consequences and next steps". The serials librarian, v. 62, n. 1-4, pp. 59-72.

https://doi.org/10.1080/0361526X.2012.652524

Nabe, Jonathan; Fowler, David C. (2015). "Leaving the 'big deal'... Five years later". The serials librarian, v. 69, n. 1, pp. 20-28.

https://doi.org/10.1080/0361526X.2015.1048037

Nicholas, David; Huntington, Paul (2006). “Electronic journals: are they used?”. Interlending and document supply, v. 34, n. 2, pp. 74-77.

https://doi.org/10.1108/02641610610669723

Nicholas, David; Rowlands, lan; Jubb, Michael; Jamali, Hamid R. (2010). "The impact of he economic downturn on libraries: With special reference to university libraries". The journal of academic librarianship, v. 36, n. 5, pp. 376-382. https://doi.org/10.1016/j.acalib.2010.06.001

Nisonger, Thomas E. (2008). "The 80/20 rule and core journals". Serials librarian, v. 55, n. 1-2, pp. 62-84. https://doi.org/10.1080/03615260801970774

Ohler, L. Angie; Depope, Leigh-Ann; Rupp-Serrano, Karen; Pitts, Joelle (2019). "Canceling the big deal: Three R1 libraries compare data, communication, and strategies". In: Proceedings of the Charleston library conference, November 4-8. https://docs.lib.purdue.edu/cgi/viewcontent.cgi?article=2153\&context=charleston

Olsson, Lisa; Lindelöw, Camilla H.; Österlund, Lovisa; Jakobsson, Frida (2020a). "Swedish researchers' responses to the cancellation of the big deal with Elsevier". Insights, v. 33, n. 1.

http://doi.org/10.1629/uksg.521

Olsson, Lisa; Lindelöw, Camilla H.; Österlund, Lovisa; Jakobsson, Frida (2020b). "Cancelling with the world's largest scholarly publisher: lessons from the Swedish experience of having no access to Elsevier". Insights v. 33, n. 1. http://doi.org/10.1629/uksg.507

Pedersen, Wayne A.; Arcand, Janet; Forbis, Mark (2014). "The big deal, interlibrary loan, and buildding the user-centered journal collection: A case study". Serials review, v. 40, n. 4, pp. 242-250.

https://doi.org/10.1080/00987913.2014.975650

Piwowar, Heather; Priem, Jason; Larivière, Vincent; Alperin, Juan-Pablo; Mattias, Lisa; Norlander, Bree; Farley, Ashley; West, Jevin; Haustein, Stefanie (2018). "The state of OA: a large-scale analysis of the prevalence and impact of open access articles". PeerJ, v. 6, e4375.

https://doi.org/10.7717/peerj.4375

Pruvot, Enora-Bennetot; Estermann, Thomas; Kupriyanova, Veronika (2017). EUA Public Funding Observatory report. https://eua.eu/resources/publications/913:eua-public-funding-observatory-report-2019-20.html

Rathmel, Angie; Currie, Lea; Enoch, Todd (2015). "Big deals and squeaky wheels: Taking stock of your stats". The serials librarian, v. 68, n. 1-4, pp. 26-37.

https://doi.org/10.1080/0361526X.2015.1013754 
Reader, Evan A. (1999). "Purchasing resources collectively: What makes a consortium successful?". The Charleston advisor, v. 1, n. 2, pp. 43-44.

Regazzi, John J. (2012). "U.S. academic library spending, staffing and utilization during the Great Recession 2008-2010". The journal of academic librarianship, v. 39, n. 3, pp. 217-222.

https://doi.org/10.1016/j.acalib.2012.12.002

Rodríguez-Bravo, Blanca; Alvite-Díez, María-Luisa (2006a). "The use of electronic journals in academic libraries in Castilla y León". In: Brophy, Peter; Craven, Jenny; Markland, Margaret (eds.). Libraries without walls 6: Evaluating the distributed delivery of library services. London: Facet Publishing, pp. 125-137. ISBN: 9781856045766

Rodríguez-Bravo, Blanca; Alvite-Díez, María-Luisa (2006b). “Uso de las revistas-e suministradas por Emerald en bibliotecas universitarias españolas (2002-2005)". El profesional de la información, v. 15, n. 6, pp. 464-472.

http://www.elprofesionaldelainformacion.com/contenidos/2006/noviembre/08.pdf

Rodríguez-Bravo, Blanca; Alvite-Díez, María-Luisa (2011). "An analysis of the use of electronic journals in an academic context: Developments and profitability". Serials review, v. 37, n. 3, pp. 118-195.

https://doi.org/10.1016/j.serrev.2011.06.003

Rodríguez-Bravo, Blanca; Alvite-Díez, María-Luisa (2013). "Impact of the consumption of electronic contents on research productivity in the universities of Castile and Leon". Library collections, acquisitions, and technical services, v. 37 , n. 3-4, pp. 85-106.

https://doi.org/10.1016/J.LCATS.2013.09.007

Rodríguez-Bravo, Blanca; Alvite-Díez, María-Luisa; Barrionuevo-Almuzara, Leticia (2012). "Trends and models in the consumption of electronic contents. An analysis of the journals most widely used in Spanish universities". Journal of academic librarianship, v. 38, n. 2, pp. 42-59.

https://doi.org/10.1016/j.acalib.2011.11.007

Rodríguez-Bravo, Blanca; Alvite-Díez, María-Luisa; Morán-Suárez, María-Antonia; Barrionuevo-Almuzara, Leticia (2008). "Patterns of use of electronic journals in Spanish university libraries". Serials review, v. 34, n. 2, pp. $115-128$. https://doi.org/10.1016/j.serrev.2008.01.002

Rodríguez-Bravo, Blanca; Alvite-Díez, María-Luisa; Morán-Suárez, María-Antonia; Marraud, Gerardo (2012). “Impacto de la contratación de colecciones de revistas electrónicas en la productividad de la Universidad de Vigo". El profesional de la información, v. 21, n. 6, pp. 585-594.

https://doi.org/10.3145/epi.2012.nov.05

Rodríguez-Bravo, Blanca; Alvite-Díez, María-Luisa; Olea, Isabel (2015). “La utilización de las revistas electrónicas en la Universidad de León (España): hábitos de consumo y satisfacción de los investigadores". Investigación bibliotecológica, v. 29, n. 66, pp. 17-55. https://doi.org/10.1016/j.ibbai.2016.02.024

Rodríguez-Bravo, Blanca; Borges, Maria-Manuel; Fernandes, Alberto-Nuno; Olea, Isabel; Oliveira, Maria-João (2013). "Hábitos de consumo y satisfacción con las revistas electrónicas de los investigadores de las universidades de Coimbra, León y Oporto". En: 60 Encontro ibérico Edicic, 2013-Globalização, ciência e informação: atas, pp. 1189-1208. ISBN: 978 9723613391

Rowse, Mark (2003). “The consortium site license: A sustainable model?”. Libri, v. 53, n. 1, pp. 1-10. https://doi.org/10.1046/j.1471-1842.2003.00421.x

Ruschoff, Carlen (2014). "Reality check. The big deal: dead or alive?”. Technicalities, v. 34, n. 2, pp. 6-9.

Russell, Byon (2019). "Guest post: The future of open access business models: APCs are not the only way?". The scholarly kitchen, Oct. 23.

https://scholarlykitchen.sspnet.org/2019/10/23/guest-post-the-future-of-open-access-business-models-apcs-are-notthe-only-way

Sanville, Thomas J. (2001). "A method out of the madness: OhioLink's collaborative response to the serial crisis: four years later progress report". Serials, v. 14, n. 2, pp. 163-177.

https://doi.org/10.1300/J123v40n01_12

Sanville, Thomas J. (2003). "The trends they are a-changing”. In: Strauch, Katina (ed.), Charleston Conference proceedings, 2001. Portsmouth: Libraries Unlimited, pp. 11-20. ISBN: 9781591580737

Schiltz, Marc (2018). "Science without publication paywalls: cOAlition S for the realisation of full and immediate open access". PLoS biology, v. 16, n. 9, e3000031.

https://doi.org/10.1371/journal.pbio.3000031 
Schonfeld, Roger (2019). "Is the value of the big deal in decline?". The Scholarly Kitchen, March 7. https://scholarlykitchen.sspnet.org/2019/03/07/value-big-deal-leakage

Schöpfel, Joachim; Leduc, Claire (2012). “Big deal and long tail: e-journal usage and subscriptions”. Library review, v. 61, n. 7, pp. 497-510. https://doi.org/10.1108/00242531211288245

Scott, Mitchell (2016). "Predicting use: CounteR usage data found to be predictive of ILL use and ILL use to be predictive of Counter use". The serials librarian, v. 71, n. 1, pp. 20-24.

https://doi.org/10.1080/0361526X.2016.1165783

Severin, Anna; Egger, Matthias; Eve, Martin-Paul; Hürlimann, Daniel (2018). “Discipline-specific open access publishing practices and barriers to change: an evidence-based review". F1000research, v. 7, n. 1925.

https://f1000research.com/articles/7-1925

Shu, Fei; Mongeon, Philippe; Haustein, Stefanie; Siler, Kyle; Alperin, Juan-Pablo; Larivière, Vincent (2018). "Is it such a big deal? On the cost of journal use in the digital era". College \& research libraries, v. 79, n. 6 pp. 785-798. https://doi.org/10.5860/crl.79.6.785

Simón-Martín, José; Arias-Coello, Alicia; Simón-Blas, Clara (2016). “The impact of the economic crisis on Spanish university libraries". Revista española de documentación científica, v. 39, n. 3, e142.

https://doi.org/10.3989/redc.2016.3.1346

Singson, Mangkholien; Hangsing, Paokholun (2015). "Implication of 80/20 rule in electronic journal usage of UGC-Infonet consortia". The journal of academic librarianship, v. 41, n. 2, pp. 207-219.

https://doi.org/10.1016/j.acalib.2014.12.002

Sjoberg, Cindy (2017). "E-journals and the big deal: A review of the literature". SLIS student research journal, v. 6, n. 2. https://doi.org/10.31979/2575-2499.060203

Springer Nature (2019). Springer Nature and ResearchGate launch first collaborative pilot.

https://group.springernature.com/gb/group/media/press-releases/springer-nature-and-researchgate-extend-contentsharing-pilot/16916562

Srivastava, Bhawana; Kumar, Sanjeev (2018). "Usage and impact of Science Direct material science package in a material science library". Desidoc. Journal of library \& information technology, v. 38, n. 1, pp. 21-26.

https://doi.org/10.14429/djlit.38.1.12124

Stachokas, George (2018). "The library in the information marketplace". In: George Stachokas (ed.), Reengineering the library: Issues in electronic resources management. Chicago: ALA, pp. 119-135. ISBN: 9780838916216

Strieb, Karla L.; Blixrud, Julia C. (2014). “Unwrapping the bundle: An examination of research libraries and the 'big deal'”. Portal: Libraries and the academy, v. 14, n. 4, pp. 603-605.

https://doi.org/10.1353/pla.2014.0027

Szprot, Jakub; Gruenpeter, Natalia; Rycko, Nikodem; Siewicz, Krzysztof; Schimmer, Ralf; Campbell, Colleen; Karlstrøm, Nina; Andenæs, Nils; Lundén, Anna; Wideberg, Britt-Marie (2021). Transformative agreements: overview, case studies, and legal análisis. Wsrszawa: Sydawnictwa ICM.

https://zenodo.org/record/4585393

Tay, Aaron (2019). "Reflections on trends in library big deals, consortiums and how it might apply to Singapore?". Musings about librarianship, May.

http://musingsaboutlibrarianship.blogspot.com/2019/05/reflections-on-trends-in-library-big.html

Tenopir, Carol; King, Donald W. (2000). Towards electronic journals: realities for scientists, librarians and publishers. Washington: Special Libraries Association. ISBN: 9780871115072

Tenopir, Carol; King, Donald W. (2002). “Reading behaviour and electronic journals”. Learned publishing, v. 15, n. 4, pp. 259-265.

https://doi.org/10.1087/095315102760319215

Tetteh, Evelin O. Apronti (2018). "Usage evaluation of electronic resources in academic and research libraries in Ghana". Global knowledge, memory and communication, v. 67, n. 4/5, pp. 316-331.

https://doi.org/10.1108/GKMC-11-2017-0097

Tripathi, Manorama; Kumar, Sunil (2014). "Use of online resources at Jawaharlal Nehru University: a quantitative study". Program, v. 48, n. 3, pp. 272-292.

https://doi.org/10.1108/PROG-11-2012-0059 
Trueswell, Richard L. (1969). "Some behavioral patterns of library users: The 80/20 rule". Wilson library bulletin, v. 43, n. 5, pp. 458-461.

University of California. Office of Scholarly Communication (2019). Negotiating with scholarly journal publishers: a toolkit from the University of California, May.

https://osc.universityofcalifornia.edu/uc-publisher-relationships/resources-for-negotiating-with-publishers/ negotiating-with-scholarly-journal-publishers-a-toolkit

Urbano, Cristóbal; Anglada, Lluís M.; Borrego, Ángel; Cantos, Carme; Cosculluela, Antonio; Comellas, Núria (2004). "The use of consortially purchased electronic journals by the CBUC (2000-2003)". D-lib magazine, v. 10, n. 6. http://www.dlib.org/dlib/june04/anglada/06anglada.html

Van-Barneveld-Biesma, Annemieke; Campbell, Colleen; Dujso, Elma; Ligtvoet, Andreas; Scholten, Chiel; Velten, Lennart; Van-der-Vooren, Robert; Van-der-Veen, Geert (2020). Read \& publish contracts in the context of a dynamic scholarly publishing system: A study on future scenarios for the scholarly publishing system. Technopolis Group. https://cutt.ly/evuKt1x

Ward, Suzanne M. (2014). "Patrons: Your new partners in collection development”. American libraries, v. 45 , n. 374. https://americanlibrariesmagazine.org/2014/04/30/patrons-your-new-partners-in-collection-development

Weicher, Maureen; Zhang, Tian-Xiao (2012). "Unbunding the 'big deal' with pay-per-view of e-journal articles". Serials librarian, v. 63, n. 1, pp. 28-37.

https://doi.org/10.1080/0361526X.2012.688167

Wenzler, John (2017). "Scholarly communication and the dilemma of collection action: Why academic journals cost too much". College \& research libraries, v. 78, n. 2, pp. 183-200.

https://doi.org/10.5860/crl.78.2.16581

Zhu, Qiandong; Xiang, Huimin (2016). “Differences of Pareto principle performance in e-resource download distribution". The electronic library, v. 34, n. 5, pp. 846-855.

https://doi.org/10.1108/EL-05-2015-0068

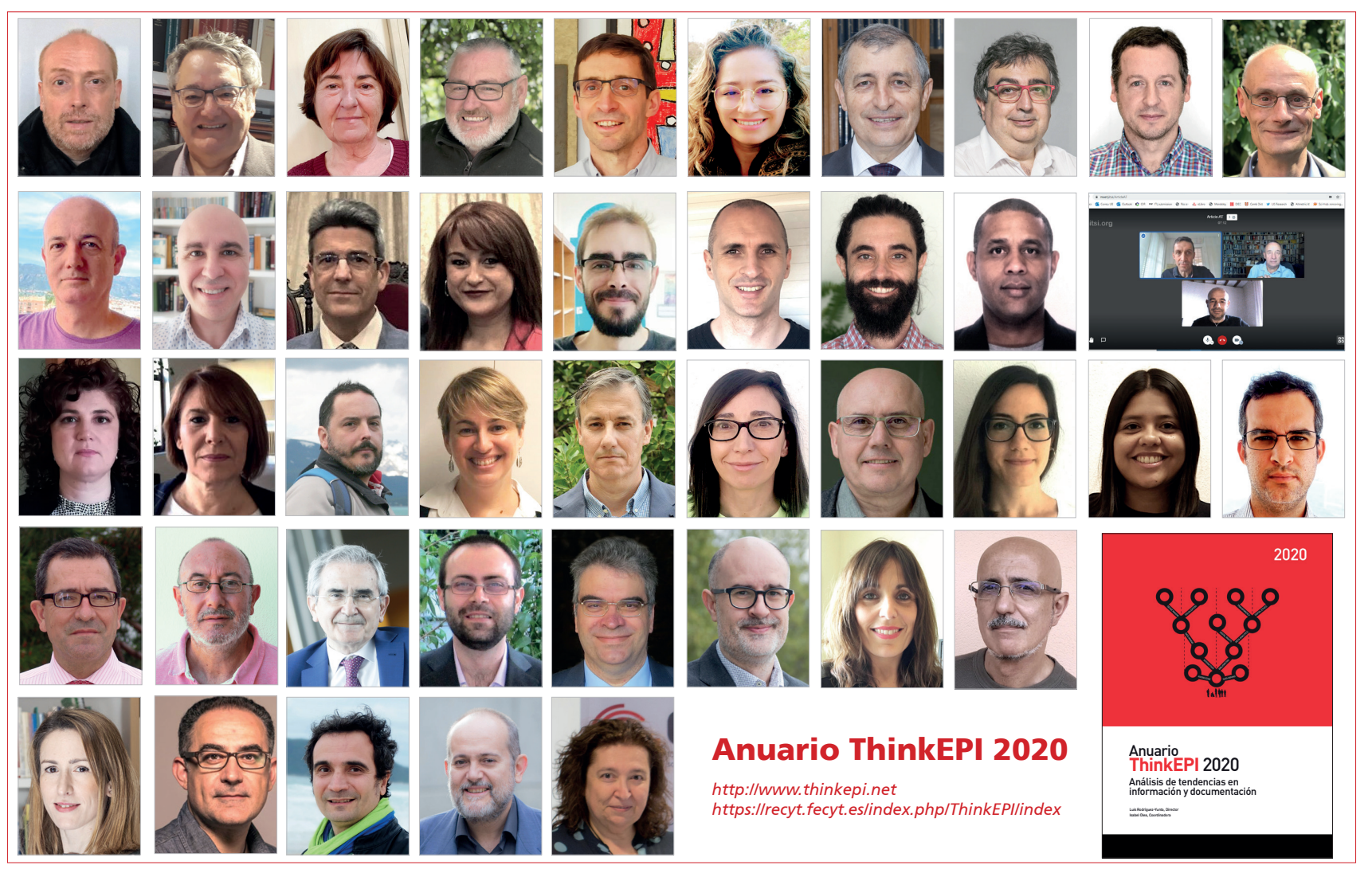

